\title{
The Frank Murphy Farm Site (41AN48), Anderson County, Texas
}

Timothy K. Perttula

Heritage Research Center, Stephen F. Austin State University

Follow this and additional works at: https://scholarworks.sfasu.edu/ita

Part of the American Material Culture Commons, Archaeological Anthropology Commons, Environmental Studies Commons, Other American Studies Commons, Other Arts and Humanities Commons, Other History of Art, Architecture, and Archaeology Commons, and the United States History Commons

Tell us how this article helped you.

This Article is brought to you for free and open access by the Center for Regional Heritage Research at SFA ScholarWorks. It has been accepted for inclusion in Index of Texas Archaeology: Open Access Gray Literature from the Lone Star State by an authorized editor of SFA ScholarWorks. For more information, please contact cdsscholarworks@sfasu.edu. 


\section{The Frank Murphy Farm Site (41AN48), Anderson County, Texas \\ Creative Commons License \\ (c) $($ ) $(9)$}

This work is licensed under a Creative Commons Attribution-NonCommercial 4.0 International License 


\section{The Frank Murphy Farm Site (41AN48), Anderson County, Texas}

Timothy K. Perttula

\section{INTRODUCTION}

The Frank Murphy Farm site (41AN48) is a Late Caddo period, Frankston phase occupation in the upper Neches River basin in the East Texas Pineywoods (Figure 1). The site was investigated by University of Texas (UT) archaeologists in 1935 (Jackson 1935).

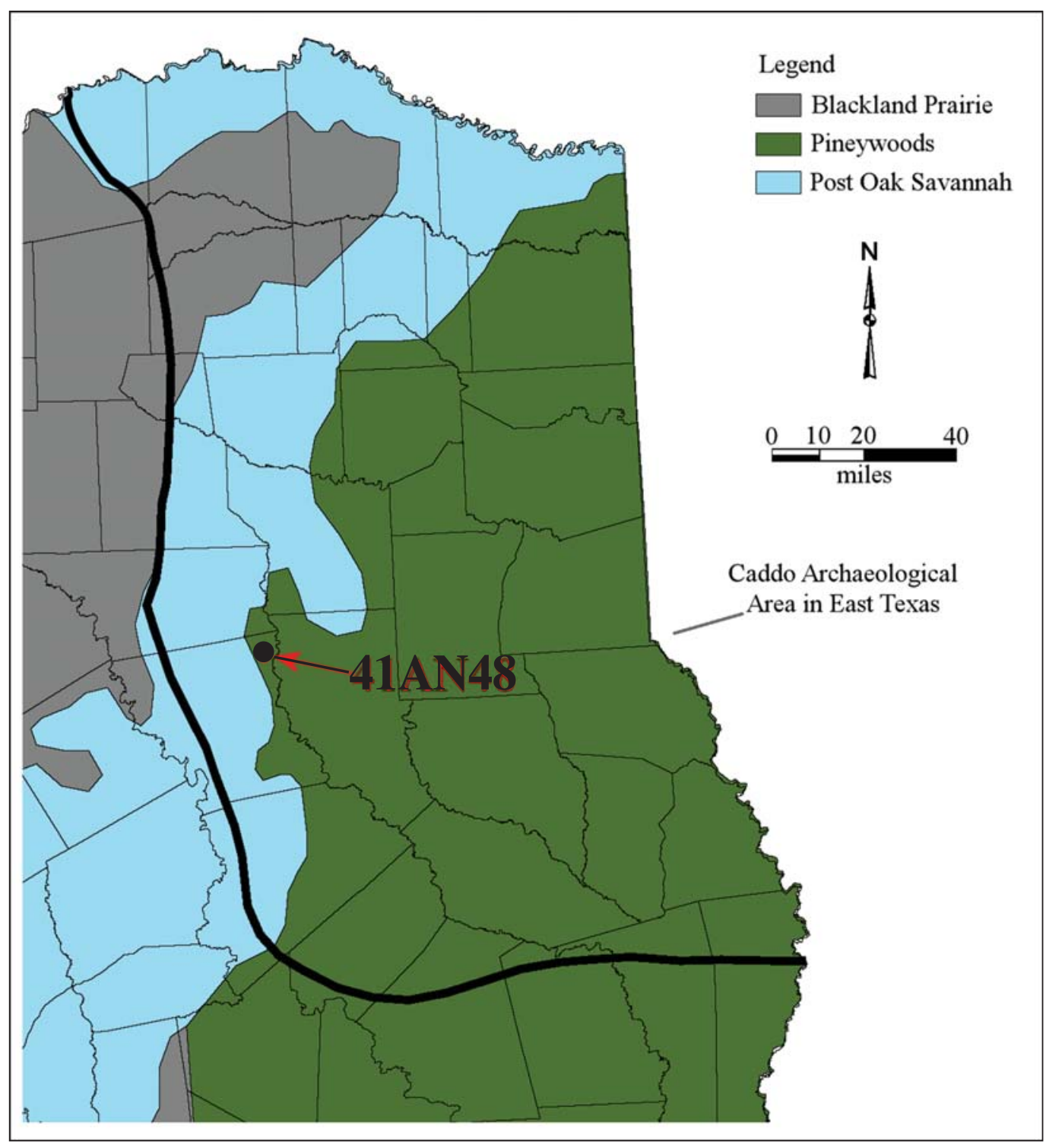

Figure 1. The location of the Frank Murphy Farm site (41AN48) in East Texas. 


\section{SITE INVESTIGATIONS}

This ancestral Caddo site was situated on the edge of a sandy upland landform in the Boggy Creek valley, about 0.5 miles southwest of the creek itself. Boggy Creek is an eastward-flowing tributary to the Neches River, about 3.2 miles to the east of the site.

According to Jackson (1935), the landowner had reported plowing up a ceramic bottle from the site, which had a well-preserved midden deposit. The midden covered a ca. 9 × $6 \mathrm{~m}$ area, with deposits that reached to ca. 46-51 cm bs. Jackson (1935) noted that ceramic sherds and animal bones were common in the midden, especially between $0-25 \mathrm{~cm}$; mussel shells were also present in the midden.

\section{ARTIFACT ASSEMBLAGE}

The Texas Archeological Research Laboratory at The University of Texas at Austin (TARL) collections from the Frank Murphy Farm site include 479 ceramic sherds, parts of two elbow pipes with incised line decorative elements, and a clay coil.

\section{Ceramic Sherds and Vessel Sections}

All of the analyzed sherds from the Frank Murphy Farm site are from grog-tempered vessels (Table 1). The 87 decorated sherds include 55 percent from utility ware vessels and 45 percent from fine ware vessels. This does not include 293 brushed body sherds that are listed on the TARL inventory forms from the site, but were not examined for this article. The absence of sherds from bone-tempered vessels is consistent with a Late Caddo period upper Neches River basin ceramic tradition site (Perttula 2011:301).

Table 1. Ceramic sherds from the Frank Murphy Farm site.

\begin{tabular}{lccc}
\hline Ware & Grog & Bone & N \\
\hline Plain & 98 & - & 98 \\
Utility & 47 & - & 47 \\
Fine & 40 & - & 40 \\
\hline Totals & 185 & - & 185 \\
\hline
\end{tabular}

Including the brushed body sherds listed in the TARL inventory, of the 380 decorated sherds, about 82 percent $(n=307$ ) have brushed decorative elements (Table 2). The plain to decorated sherd ratio is a low 0.26. The combination of high proportions of brushed sherds and a low plain to decorated sherd ratio suggests the ancestral Caddo occupation at the Frank Murphy site was late in the Frankston phase, likely after A.D. 1560 (see Perttula 2011:Table 6-38).

Table 2. Utility ware sherds from the Frank Murphy Farm site.

\begin{tabular}{lcr}
\hline $\begin{array}{l}\text { Decorative method/ } \\
\text { Decorative element }\end{array}$ & $\mathrm{N}$ & Percent \\
\hline Appliqued & & 03 \\
large appliqued node & 1 & 0.3 \\
straight appliqued fillet & 1 &
\end{tabular}


Table 2. Utility ware sherds from the Frank Murphy Farm site, cont.

Decorative method/

$\mathrm{N}$

Percent

Decorative element

\section{Brushed}

brushed body sherds

293

86.2

diagonal brushed rim

horizontal brushed rim or body

5

4

1.5

overlapping brushed

vertical brushed rim or body

\section{Brushed-Incised}

opposed brushed and overlying cross-hatched lines

parallel brushed-incised

\section{Brushed-Pinched}

horizontal brushed rim and pinched ridges on handle

\section{Brushed-Punctated}

diagonal brushed on rim; tool punctated

rows through the brushing

horizontal-vertical brushed with tool

punctates through the brushing

parallel brushed-fingernail punctated

rows through the brushing

circular punctated row (lower rim) and

\section{Grooved}

parallel grooves

\section{Incised}

vertical lines on rim and lip

\section{Neck Banded}

horizontal neck bands

\section{Punctated}

rows of circular punctates on handle tool punctated rows 
The many brushed sherds from the midden deposits are from Bullard Brushed jars. So too are the brushed-incised, brushed-pinched, and brushed-punctated sherds in the assemblage (Figure 2). The one brushed-pinched sherd is a jar rim with horizontal brushing; the strap handle attached to the rim is decorated with three pinched ridges. Another rim with a vertical attached handle is decorated with rows of circular punctations on one side of the handle (see Table 2). One plain rim sherd has an appliqued lug handle. Two sherds have either a large appliqued node or a straight appliqued fillet on the body of two different vessels.

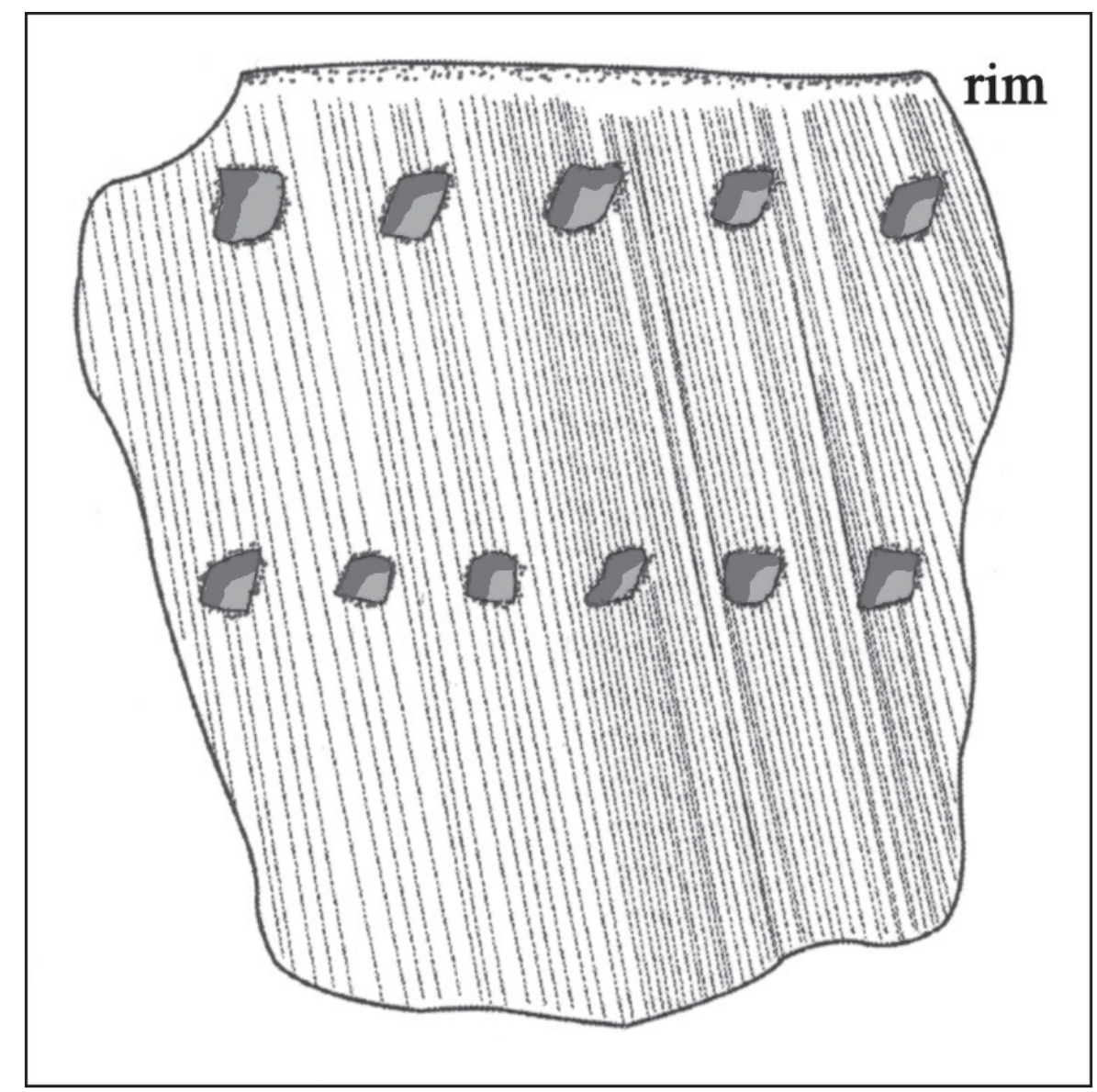

Figure 2. Brushed-punctated rim sherd from the Frank Murphy Farm site.

The grooved sherds are from Lindsey Grooved vessels (see Marceaux 2011), a utility ware type found in the upper Neches and Angelina River basins on Caddo sites thought to date after ca. A.D. 1680. Other utility ware types represented in the Frank Murphy Farm ceramic assemblage includes a vertically incised Maydelle Incised rim and six rim and body sherds from La Rue Neck Banded jars (see Table 2).

There are three vessel sections from fine ware vessels in the midden deposits. The first is a grog-tempered Poynor Engraved, var. Hood (see Perttula 2011:Figure 6-64e) globular carinated bowl (Figure 3). The second vessel section is also from a grog-tempered globular carinated bowl, but this vessel section has only a horizontal engraved line at the carination. The third vessel section is from a possible Hume Engraved, var. Allen grog-tempered bottle (Figure 4) - this variety of Hume Engraved is typically identified on bowls - or var. unspecified (see Perttula 2011:Figure 6-66g) absent the vertical cross-hatched panels. It has three horizontal engraved lines along the upper vessel body, and the lowermost horizontal engraved has large excised pendant triangles.

The fine ware sherds are from vessels that have either engraved (95 percent) or engraved-brushed (5 percent) decorative elements (Table 3). With the exception of one possible Hume Engraved bottle sherd 


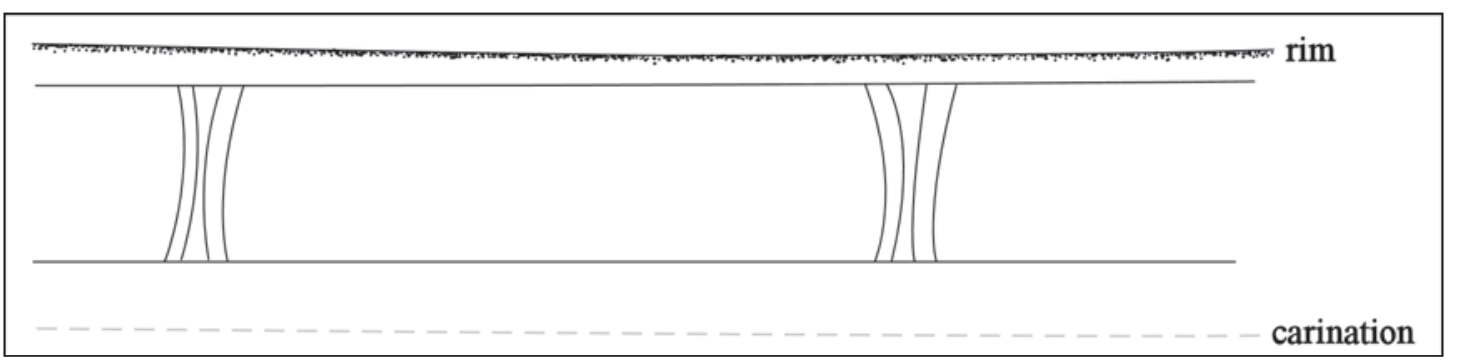

Figure 3. Poynor Engraved, var. Hood carinated bowl vessel section from the Frank Murphy Farm site.

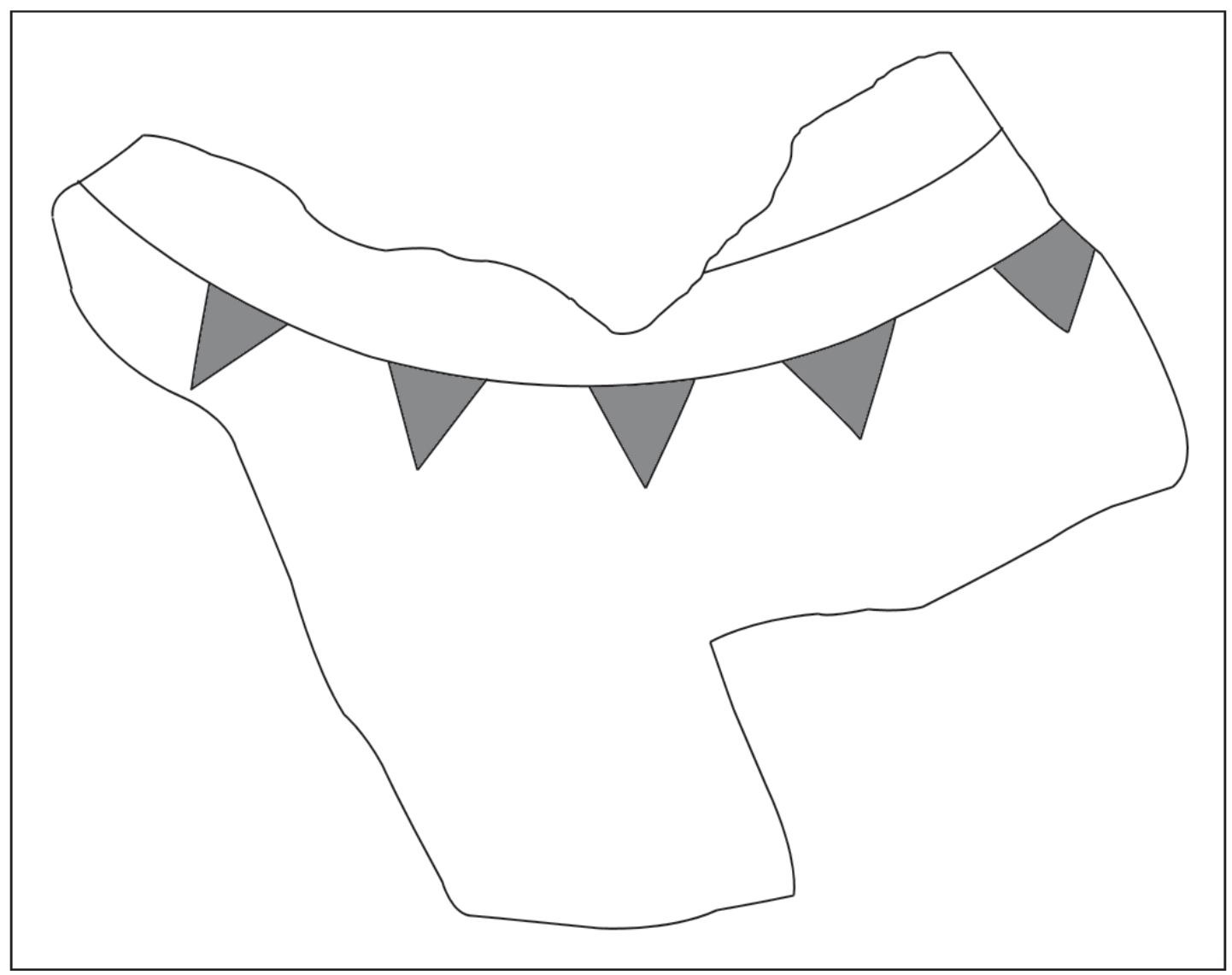

Figure 4. Possible Hume Engraved, var. Allen or var. unspecified bottle vessel section from the Frank Murphy Farm site.

with vertical lines on the vessel body, the remainder of the engraved and engraved-brushed sherds from the Frank Murphy Farm are from two varieties of Poynor Engraved carinated bowls: var. Cook and var. Hood (Perttula 2011:Figure 6-64c-e). Two of the sherds, both from Poynor Engraved, var. Cook vessels, have a white kaolin clay pigment rubbed in the engraved lines.

The six Poynor Engraved, var. Hood sherds have horizontal engraved rim panels divided by a series of cross-hatched brackets (Figure 5a-c). The Poynor Engraved, var. Cook sherds ( $\mathrm{n}=27$, or 67.5 percent of the engraved sherds in the assemblage) have sets of curvilinear to vertical arcing lines (usually three lines) forming ovals on the rim panel (Figure 6a-d). One of the var. Cook carinated bowl rim sherds has horizontal brushing marks on the vessel body (Figure 6d). 
Table 3. Fine ware sherds from the Frank Murphy Farm site.

Decorative method/

$\mathrm{N}$

Percent

Decorative element

\section{Engraved}

sets of curvilinear to vertical arcing

lines and horizontal line under lip

sets of curvilinear to vertical arcing lines

and horizontal line at carina

sets of curvilinear to vertical arcing lines

horizontal panel divided by cross-

hatched brackets

horizontal line under lip

parallel lines

straight line

5.0

vertical lines

\section{Engraved-Brushed}

sets of curvilinear to vertical arcing lines

and horizontal line at carina and under lip; horizontal brushed body horizontal line at carina; horizontal brushed body

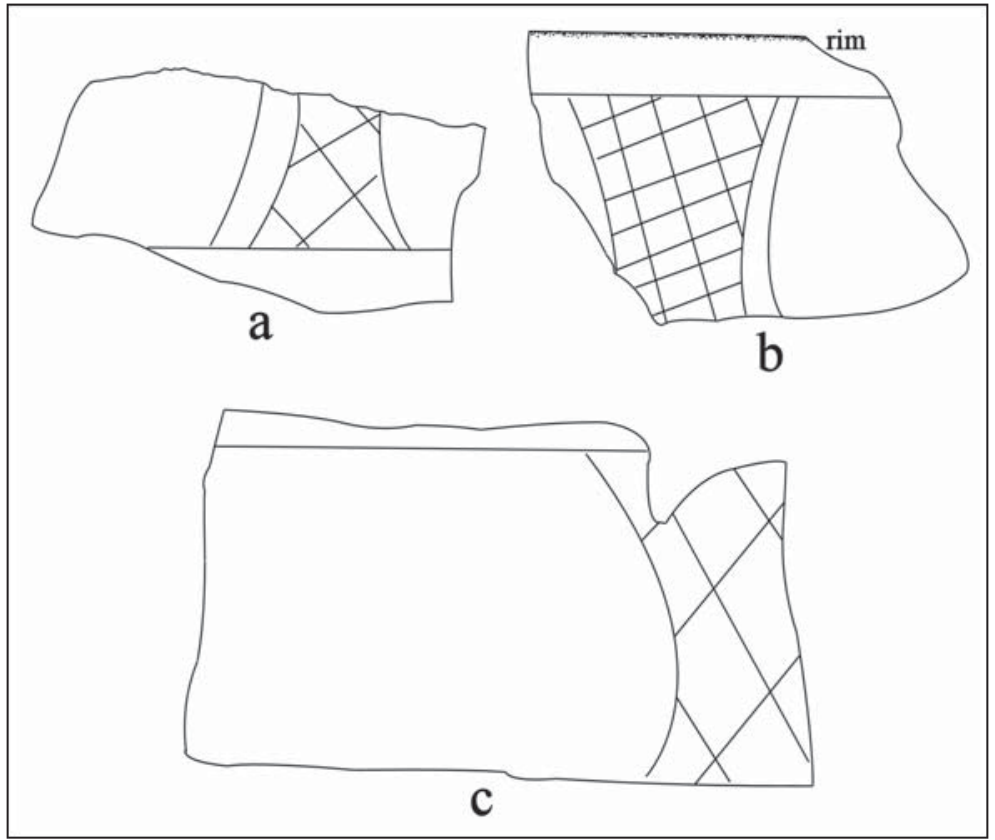

Figure 5. Poynor Engraved, var. Hood rim sherds from the Frank Murphy Farm site. 


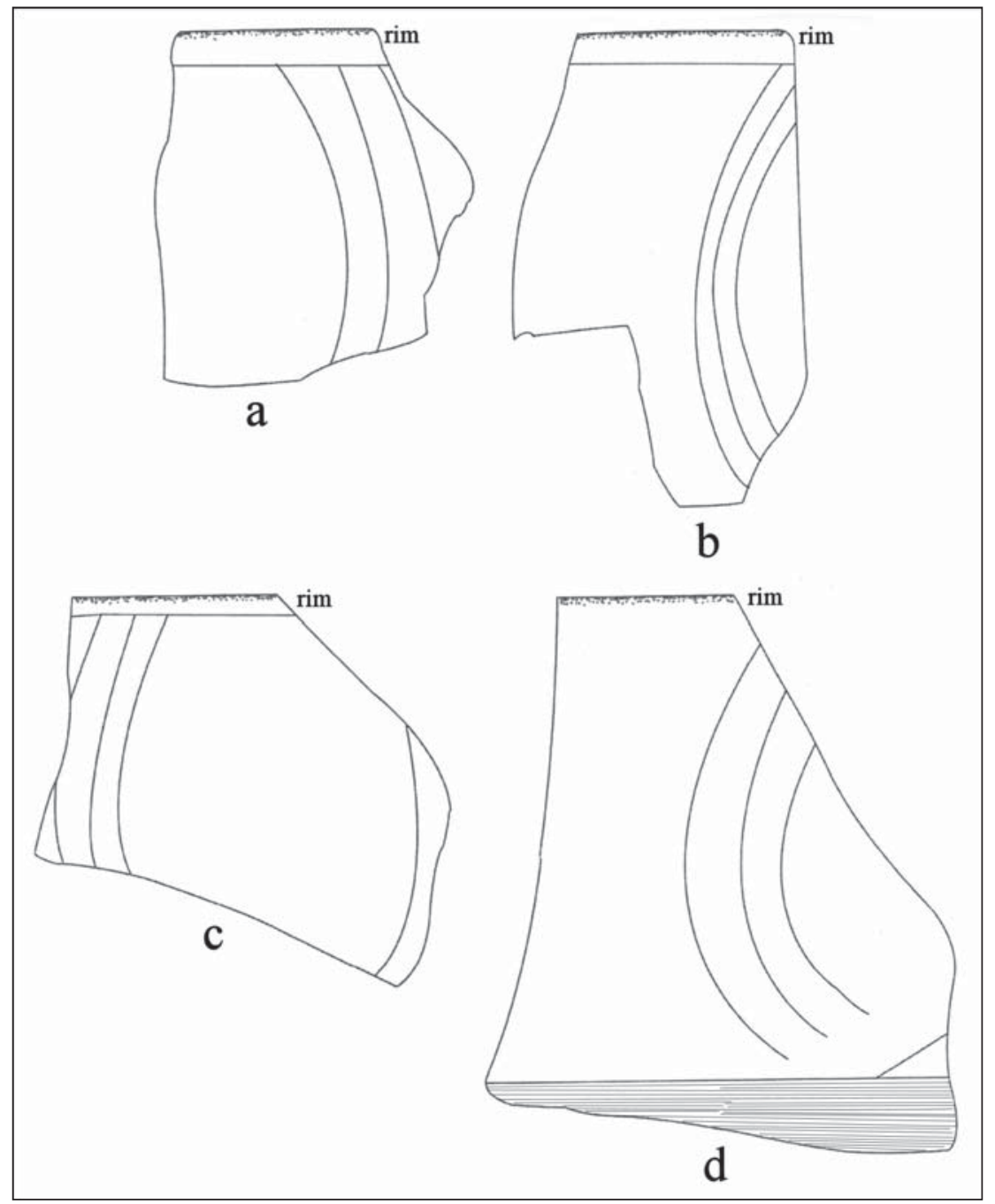

Figure 6. Poynor Engraved, var. Cook rim sherds from the Frank Murphy Farm site.

\section{Ceramic Pipes}

There are pieces of two ceramic elbow pipes in the midden deposits. Both are Var. C elbow pipes (Perttula 2011:215 and Figures 6-23 and 6-24b-c), which were made by the Caddo between ca. A.D. 1400-1650 in the upper Neches River basin. These pipes have incised lines on the stem as well as incised lines on the pipe that extend along the entirety of the stem and/or the basal portions of the bowl.

The first pipe fragment from the Frank Murphy Farm site is a grog-tempered stem, and it has four horizontal incised lines on the stem. The stem's exterior diameter is $22.0 \mathrm{~mm}$, and its interior orifice diameter is $12.7 \mathrm{~mm}$. The second elbow pipe is part of a pipe stem and flaring rim bowl (Figure 7). It was found at a depth of ca. $20 \mathrm{~cm}$ in the midden (Jackson 1935). The pipe stem has three horizontal incised lines. The stem on this pipe has an exterior diameter of $18.8 \mathrm{~mm}$ and an interior orifice diameter of $9.9 \mathrm{~mm}$. 


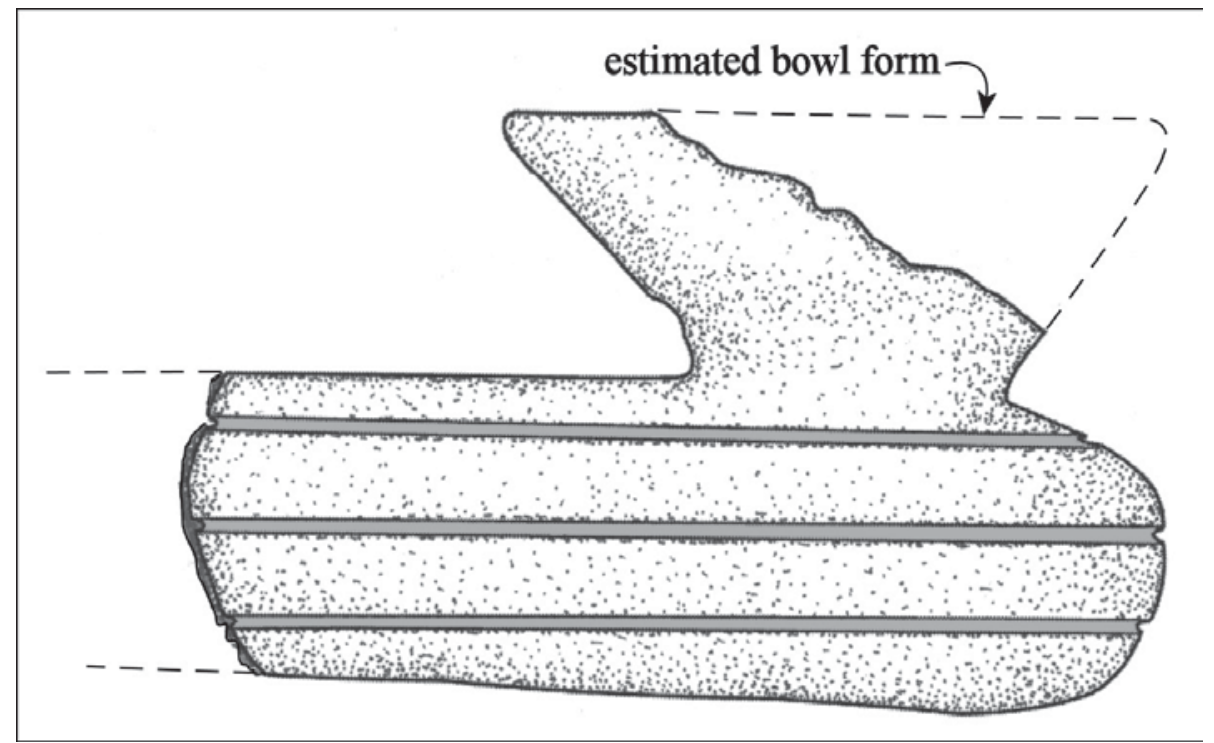

Figure 7. Incised elbow pipe from the Frank Murphy Farm site.

\section{Other Clay Artifacts}

The one remaining clay artifact in the artifact assemblage is a $98 \times 22 \mathrm{~mm}$ long and wide clay coil. The clay has two roughly incised lines encircling one end of the coil. Jackson (1935) noted the clay coil was recovered from ca. $25 \mathrm{~cm}$ in the midden deposits.

\section{SUMMARY AND CONCLUSIONS}

The Frank Murphy Farm site (41AN48) is an ancestral Caddo settlement marked by a well-preserved midden deposit along Boggy Creek, a tributary to the Neches River in the upper Neches River basin in the East Texas Pineywoods. University of Texas archaeologists excavated in the midden deposits in 1935 and recovered an assemblage of Caddo ceramic sherds and elbow pipe fragments (from a variety of elbow pipe that was manufactured between ca. A.D. 1400-1650 in the river basin).

The ceramic assemblage from the site is dominated by sherds from brushed utility ware vessels, as well as an interested assortment of sherds from Late Caddo period Frankston phase fine ware carinated bowls and bottles. The fine ware sherds include Poynor Engraved, var. Cook and var. Hood carinated bowls and a Hume Engraved bottle. Seriation analysis of ceramic vessels from burial features in upper Neches River basin Caddo sites suggests that the Frank Murphy Farm site was occupied after ca. A.D. 1480. This is based on the indication that Hume Engraved bottles were not made until after ca. A.D. 1480, and that both varieties of Poynor Engraved are by far most common in sub-phase 2 of the Frankston phase, from ca. A.D. 1480-1560 (Perttula 2011:268 and Table 6-37). Nevertheless, both Poynor Engraved varieties continued to be made in sub-phase 3 (ca. A.D. 1560-1650) of the Frankston phase, which would be consistent with the occurrence of a few Lindsey Grooved sherds in the utility wares, along with the high proportion of brushed sherds among all the decorated sherds and the very low $(0.26)$ plain to decorated sherd ratio.

\section{ACKNOWLEDGMENTS}

Jonathan Jarvis of the Texas Archeological Research Laboratory, The University of Texas at Austin facilitated access to the collections and records from the Frank Murphy Farm site. Lance Trask prepared the figures in this article. 


\section{REFERENCES CITED}

Jackson, A. T.

1935 Notes on Field Work, Frank Murphy Farm, 1/4 Mile Northeast of Freeman Springs, 1/4 Mile North of Dobbs Cemetery, Anderson County, September 28, 1935. MS on file, Texas Archeological Research Laboratory, The University of Texas at Austin.

Marceaux, P. S.

2011 The Archaeology and Ethnohistory of the Hasinai Caddo: Material Culture and the Course of European Contact. Ph.D. dissertation, Department of Anthropology, The University of Texas at Austin.

Perttula, T. K.

2011 The Ceramic Artifacts from the Lang Pasture Site (41AN38) and the Place of the Site within an Upper Neches River Basin Caddo Ceramic Tradition. In Archeological Investigations at the Lang Pasture Site (41AN38) in the Upper Neches River Basin of East Texas, assembled and edited by T. K. Perttula, D. B. Kelley, and R. A. Ricklis, pp. 145-320. Archeological Studies Program Report No. 129, Texas Department of Transportation, Environmental Affairs Division, Austin. 